\title{
Hunian Berulang Situs Gua Macan (Tinjauan Berdasarkan Data Arkeologi dan Geologi)
}

Indah Asikin Nurani

Keywords: subsistence, natural resources, settlement, cave, prehistory, exploitation

\section{How to Cite:}

Nurani, I. A. (1996). Hunian Berulang Situs Gua Macan (Tinjauan Berdasarkan Data Arkeologi dan Geologi). Berkala Arkeologi, 16(2), 12-27. https://doi.org/10.30883/jba.v16i2.750

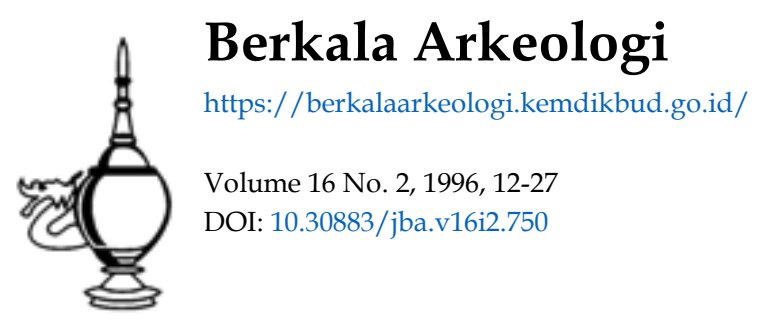

\section{cc) (7) (2)}

This work is licensed under a Creative Commons Attribution-NonCommercial-ShareAlike $\underline{4.0 \text { International License. }}$ 


\title{
HUNIAN BERULANG SITUS GUA MACAN \\ (Tinjauan Berdasarkan Data Arkeologi dan Geologi)
}

\author{
Indah Asikin Nurani \\ (Balai Arkeologi Yogyakarta)
}

\section{Pendahuluan}

Kehidupan di gua (cave) atau ceruk (rock shelter) merupakan pola hidup yang terjadi pada kala plestosen akhir hingga kala holosen. Kehidupan yang berlangsung saat itu merupakan kehidupan yang masih sangat bergantung pada potensi ekologi sekitarnya. Mereka masih bertempat tinggal secara berpindah-pindah. Kepindahan dari gua satu ke gua lainnya semata-mata didasari pada ketersediaan kebutuhan hidup mereka terutama dari flora dan fauna yang menjadi sumber makanan mereka.

Kehidupan yang bergantung sepenuhnya pada potensi ekologis sekitarnya tersebut juga didukung dengan aktivitas pembuatan perkakas sebagai sarana aktivitas mereka. Mereka menggunakan alat-alat yang dibuat dari beberapa bahan yaitu batu, tulang, tanduk, kulit kerang, dan kayu yang tersedia di lingkungan sekitarnya. Dalam pembuatan suatu alat juga ditentukan keadaan lingkungan sekitarnya. Dengan demikian, dapat disimpulkan bahwa suatu lingkungan tertentu akan mengakibatkan aktivitas teknologi yang tertentu pula.

Pembahasan mengenai kehidupan di gua-gua ataupun di ceruk belum begitu banyak dilakukan, terutama mengenai rekonstruksi pola hidup mereka. Pembahasan mengenai budaya penghuni gua yang ada selama ini menurut Simanjuntak (1996) dikelompokkan menjadi beberapa budaya yang meliputi budaya serpih bilah, budaya hoabinhian, budaya lukisan dinding gua, dan budaya Sampung. Semua budaya tersebut meliputi batas ruang dan waktu yang berbeda-beda.

Budaya serpih bilah ciri utamanya adalah industri serpih dan bilah sebagai produk utama penghuni gua. Budaya ini paling luas persebarannya dengan inovasi produk lokal yang khas pada masingmasing tempat. Mata panah dengan dasar cekung berkembang di Jawa Timur, lancipan bertangkai di Timor, mata panah bergerigi di Sulawesi Selatan, dan bilah memanjang dengan retus bersayap di sepanjang Sungai Nulbaki (Timor barat).

Budaya hoabinhian persebarannya lebih sempit dari pada budaya serpih bilah, yaitu mendominasi daerah pesisir timur Sumatera dan beberapa tempat di Jawa. Pola hidupnya cenderung bergantung pada 
subsistensi dengan eksploitasi sumberdaya aquatik. Sementara itu, budaya Sampung mendominasi wilayah Jawa Timur dengan ciii utamanya berupa industri tulang, batu, dan cangkang kerang.

Budaya lukisan dinding gua umumnya menempati indonesia bagian timur. Budaya ini hingga sekarang belum pernah ditemukan di Jawa dan Sumatera. Kemungkinan pulau tersebut tidak tersentuh budaya itu ataukah tidak sesuai dengan kondisi lingkungan di Jawa dan Sumatera. Untuk membuktikan hal itu, masih diperlukan penelitian lebih lanjut.

Berangkat dari terbatasnya penelitian mengenai permukiman gua, maka tulisan ini diharapkan akan menjelaskan mengenai pemukiman secara berpindah-pindah dengan studi kasus Gua Macan. Masalah yang mendasari tulisan ini adalah apakah yang melatari kehidupan berpindahpindah tersebut? dan pola adaptasi yang bagaimanakah yang disiasati untuk memenuhi pola hidupnya?

\section{Pendekatan Studi}

Sehubungan dengan pola hidup yang masih menggantungkan pada potensi ekologi sekitarnya, maka pemahaman tentang manusia dan kebudayaan yang diciptakannya tidak berhenti pada benda-benda yang ditinggalkannya saja. Akan tetapi pembahasan akan dikaitkan dan mempertimbangkan keseluruhan data arkeologi yang ada pada situs. situs, baik yang berbentuk artefak, ekofak, fitur, dan lingkungan fisiknya sebagai satu satuan ruang analisis (Binfort, 1982; Mundarjito, 1993).

Penjabaran Mundarjito (1994) sehubungan dengan studi arkeologi ekologi adalah sebagai berikut. Arkeologi-ekologi atau ekoarkeologi adalah studi yang berusaha mengkaji hubungan antara manusia beserta kebudayaannya dengan aspek lingkungan alam. Dalam aspek manusia dan kebudayaan, dipelajari wujud kebudayaan materi yang ditemukan di situs berupa himpunan benda arkeologi yang memiliki dimensidimensinya (bentuk, ruang, dan waktu) dengan atriputnya (bentuk, ukuran, teknologi, gaya, dll). Sedangkan dari lingkungan alam dipelajari wujud benda abiotik (lahan, air, dan iklim) dan biotik (flora dan fauna). Dalam arkeologi, aspek lingkungan yang disertakan dalam kajiannya ini kemudian dikenal dengan istilah ekofak yang biasa didefinisikan sebagai benda alam yang bukan artefak, tapi mempunyai relevansi dengan manusia dan kebudayaannya.

Fokus perhatian utama dari kajian semacam ini bukan pada aspek kebudayaan (benda arkeologi) dan aspek lingkungan alam secara sendiri-sendiri, melainkan pada hubungan kedua aspek tersebut. Hubungan itu dilihat dalam satuan ruang analisis tertentu (skala mikro, 
meso, dan makro) dan mendapat perlakukan analisis secara kontekstual. Namun demikian, tidak berarti bahwa penelitian arkeologi-ekologi tidak menganggap perlu melakukan pengkajian secara spesifik terhadap benda arkeologi dengan sudut pandang morfologi (dimensi bentuk) maupun kronologi (dimensi waktu). Fokus perhatian ini menuntut data lokasi atau kelstakan benda-benda arkeologi in situ (dimensi ruang) yang tepat dan rinci, serta keterangan mengenai keadaan lingkungan alam di sekitar benda-benda arkeologi itu. Oleh karenanya selain perhatian pada aspek lingkungan alam dan hubungannya dengan kebudayaan, ciri lain dari kajian arkeologi-ekologi ialah perhatian yang besar kepada dimensi keruangan (spatiaf). Dengan demikian kajian arkeologi-ekologi bersentuhan dengan cara bernalar dan cara bekerja dalam bidang ilmu lain seperti ekologi, antropologi, geografi, geologi, sosiologi, arsitektur, dan studi regional.

Variabel morfologi (atribut bentuk, teknologi, dan stilistik), variabel umur atau kronologinya, serta variabel struktur atau bentuk susunan atau konfigurasi sebarannya merupakan variabel penting dalam kajian ekoarkeologi ini. Persamaan dan perbedaan variabel-variabel ini dapat dipakai untuk tahap analisis selanjutnye dalam upaya memperoleh data mengenai kompieksitas dan hirarki situs (teori Central Place), pelapisan komunitas manusia (struktur sosial), jaringan ekonomi (teori upstreamdownstreem pattern), pemekaran atau pertumbuhan situs dan wilayah, perkembangan teknologi dan adaptasi (teori odaptive strategy). pemanfaatan ruang sumberdaya aiam (teori cetchment area), pola tata ruang, dan perkembangan gagasan (teori simbolik), serta berbagai tujuan lain. Pendek kata keberadaan data mengenai hubungan tinggalan arkeologi dan lingkungan selanjutnya dapat dikembangkan dalam tahap analisis dan tahap penjelasan mengenai sistem teknologi, sistem sosial, dan sistem ideologi (Mundarjito, 1994).

Berkaitan dengan pendekatan studi ekoarkeologi, tidak dapat dipisahkan dari pendekatan secara geografis. Hąl tersebut sehubungan dengan pembahasan mengenai studi spatiel dan keletakan situs Menurut Haggett (1979) (dalam Sutikno, 1996), kajian geografi dapat dilakukan salah satu dari tiga pendekatan berikut.

a Pendekatan spatial (keruangan): pendekatan ini menekankan pada analisis variasi distribusi dan lokasi fenomena atau kelompok fenomena yang terdapat di permukaan bumi; sebagai contoh: variasi temuan pada suatu situs arkeologi dan variasi kerusakkannya. Dalam pendekatan keruangan ini terdapat tiga dimensi keruangan Ketiga 
dimensi ruang tersebut sering dikaitkan dengan dimensi waktu (temporal dimension).

b. Pendekatan ekologis menekankan pada studi hubungan antata variabel kemanusiaan dengan variabel lingkungan. Pendekatan ini ingin menjelaskan hubungan logis dari suatu daerah padat penduduk dengan daerah lain yang jarang penduduk; mengapa pada suatu situs di lereng api kaya akan temuan permukiman kuno, daripada temuan di perbukitan lipatan miskin temuan.

c. Pendekatan kompleks wilayah: pendekatan ini merupakan penggabungan antara pendekatan spatia/ dengan pendekatan ekologis. Setiap wilayah dikaji, kemudian dievaluasi persamaan dan perbedaannya, sehingga dapat diketahui faktor penyebab perbedaan tersebut Hubungan fungsional dari masing-masing wilayah dapat dianalisis, sehingga dapat diketahui inti permasalahan dan kecenderungan pengembang-an wilayah. Hasil analisis kompleks wilayah ke wilayah tersebut dapat memahami suatu proses aliran barang atau jasa dari suatu wilayah ke wilayah yang lain, sebagai akibat adanya perbedaan fenomena di setiap wilayah tersebut.

\section{Perolehan Data}

Gua Macan merupakan salah satu gua yang berada pada kaki utara Gunung Watangan. Secara administratif kompleks gua ini berada di Desa Lojejer, Kecamatan Wuluhan, Kabupaten Jember, Jawa Timur. Keadaan geografis situs gua ini berada pada lingkungan daerah perbukitan kapur selatan yang merupakan kawasan hutan jati. Di sebelah utara dan barat daerah ini terbentang dataran rendah Lumajang yang subur. Bagian barat dibatasi oleh beberapa bukit kapur yang diteruskan dengan dataran rendah yang bergabung dengan Pantai Puger, sedangkan bagian selatan dibatasi Gunung Watangan. Kira-kira $700 \mathrm{~m}$ arah utara terdapat Sungal Kepel yang merupakan anak Sunga: Bedadung yang mengalir menuju ke Samudera Indonesia. Daerah sepanjang sungai ini merupakan daerah yang subur dan oleh penduduk setempat dimanfaatkan sebagai daerah persawahan (lihat gambar 1)

Gua Macan terletak di bagian paling selatan kaki Gunung Watangan. Kondisi gua masih baik dan belum terganggu dengan arah hadap gua ke timurlaut. Lapisan tanah di gua itu tampak sangat tebal dan terbentang luas dengan ukuran panjang sekitar $17 \mathrm{~m}$ dan lebar gua $7 \mathrm{~m}$ Atap gua memiliki tinggi tidak beraturan yaitu antara $2.25 \mathrm{~m}$ sampai dengan $8 \mathrm{~m}$ (lihat gambar 2)

Berdasarkan penelit1an yang telah dilakukan oieh Balai Arkeolog! Yogyakarta di Gua Macan telah berhasil ditemukan beberapa data 
penting baik berupa data arkeologi maupun data geologi Berikut akan dijabarkan data-data tersebut.

\subsection{Data Arkeologi}

Hasil ekskavasi yang telah dilakukan pada Gua Macan menunjukkan bahwa gua ini pernah dihuni oleh manusia pada masa prasejarah. Manusia penghuni gua ini hidup dengan mengkonsumsi kerang sebagai makanan utamanya. Hal ini terbukti dengan temuan yang terkandung pada kotak F-5 (gastropoda), C-6 (pelecypoda), D-5 (pelecypoda), dan C-8 (gastropoda dan pelecypoda) dalam lapisan kerang yang cukup tebal (sekitar $100 \cdot 200 \mathrm{~cm}$ ). Selain digunakan sebagai konsumsi utama penghuni gua, kerang terutama cangkangnya dimanfaatkan sebagai peralatan (sebagai serut) dan digunakan juga untuk perhiasan (berlobang). Berdasarkan hasil penelitian selama ini menunjukkan penghuni gua tidak melakukan aktivitas perburuan. Hal tersebut terbukti dengan tidak ditemukannya tulang-tulang binatang darat (vertebrata) maupun alat-alat batu atau tulang yang menunjukkan aktivitas tersebut.

Sehubungan dengan pengolahan makanan tidak dapat dilepaskan dengan peralatan yang digunakan untuk mendukung aktivitas tersebut. Urituk memperoleh dan mengolah makanan digunakan alat-alat dari batu gamping kersikan dan kerang. Hal tersebut terbukti dengan ditemukannya alat-alat dari batu pada setiap kotak yang digali. Alat-alat batu sebagian besar ditemukan di kotak D-2; D-5; dan D-3, sedangkan alat dari kerang sebagian besar ditemukan pada lapisan kerang terutama pada kotak D-5, F-5, C-6 dan C-8. Selain ditemukan alat-alat yang sudah jadi yaitu meliputi kapak perimbas, kapak penetak, pembelah, serut, serpih, bilah, juga ditemukan beberapa batu inti (sisa bahan dasar alat), tatal-tatal (serpihan) batu, batu dipangkas (limbah pembuatan alat), dan calon-calon alat (calon mata panah dan beberapa alat yang belum dipakai). Hal ini menunjukkan bahwa alat-alat batu tersebut sebagian bosar dibuat di dalam gua. Penggunaan alat-alat batu tidak dilakukan secara intensif hal tersebut dikarenakan tuntutan kebutuhan hidup mereka tidak menuntut peralatan yang kuat.

Berdasarkan temuan alat-alat batu yang ada menunjukkan bahwa penghuni Gua Macan memiliki keahlian teknologi yang baik, hal tersebut dibuktikan dengan kondisi materi bahan yang relatif jelek telah menghasilkan peralatan yang baik dan mampu menghasilkan penyerpihan yang baik Sehingga dapat disimpulkan bahwa pengendalian dalam pembuatan peralatan batu tersebut sudah dikuasai dengan baik oleh penghuni gua 


\subsection{Data Geologi}

Data geologi yang ditemukan di Gua Macan yang paling utama adalah stratigrafi berupa lapisan budaya. Berdasarkan pada hasil ekskavasi pada kotak D-5 secara lengkap dapat diketahui waktu penghunian oleh manusia di Gua Macan masa itu Stratigrafi yang ditemukan terdin dari tiga lapisan budaya (lihat gambar 4), yang berurutan dari bawah ke atas sebagai berikut.

\subsubsection{Lapisan C}

Lapisan ini merupakan lapisan tertua yang terletak persis di atas lapisan steril (nonbudaya). Ciri lapisan ini adalah bemarna coklat tua, kompak, liat, porositas sedang, mengandung cangkang pelecypoda dan alat-alat masif. Struktur tanah masif terdapat sisipan batu-batu gamping berukuran kerikil sampai bongkah. Hubungan dengan lapisan budaya B tidak selaras yang dapat dilihat dengan jelas pada hubungan antara lapisan $B$ dengan lapisan budaya $\mathrm{C}$.

\subsubsection{Lapisan B}

Lapisan budaya ini dicirikan dengan warna coklat muda. tidak kompak, porositas sangat baik, dan terdapat sisipan batu gamping. batu lempung tufaan, dan batu lempung. Cangkang pelecypoda tampak terlihat adanya orientasi arah tertentu dengan konteks temuan alat-alat masif, Eksistensi sisipan batuan seolah-olah mengambang pada masa dasar, sedangkan orientasi arah cangkang tampak teratur. Lapisan dengan kondisi tersebut tampak jelas pernah terjadi erosi yang merombak lapisan ini pada suatu waktu.

\subsubsection{Lapisan A}

Lapisan budaya A merupakan lapisan yang paling muda yaitu lapisan resen. Awal lapisan ini ditandai dengan adanya konǵlomerat alas berukuran kerikil sampai bongkah, tanah tidak kompak, berwarna coklat muda dan terdapat cangkang pelecypoda. Kuantitas cangkang tampak sangat sedikit dibandingkan kandungan cangkang pada lapisan di bawahnya yang lebih tua. Endapan ini menunjukkan endapan yang berumur relatif muda, sedangkan material pembentuknya berasal dari endapan sekitarnya yang tererosi. 


\section{Pembahasan}

Berdasarkan uraian di atas dapat diketahui adanya beberapa ha! menarik untuk dibahas lebih mendalam terutama yang berkaitan dengan pola hunian yang terjadi di Gua Macan. Pembahasan akan dijabarkan menurut data yang didapat baik data arkeologi maupun data geologi. dengan menerapkan konsepsi yang ada yaitu studi arkeologi-ekologi dan pendekatan geografi.

Temuan arkeologis yang menarik adalah industri litik dan sampah dapur berupa lapisan kerang setebal lebih kurang $2 \mathrm{~m}$. Industri litik dalam hal ini lebih diutamakan pembahasannya pada temuan kotak D-2 dan D5. Hal tersebut sehubungan dengan signifikan temuan industri litik di kedua kotak Sementara itu, perolehan makanan utama kerang laut dan darat lebih cenderung pada pembahasan dari subsistensi dengan eksploitasi biota laut.

industri litik yang ditemukan didominasi oleh alat-alat masif. Alatalat batu yang ditemukan antara lain kapak perimbas, kapak penetak. batu pukul, pembelah, dan beberapa alat-alat non masif seperti serpih, bilah, dan serut. Berdasarkan bahan baku (batu) yang tersedia di sekitar gua relatif rendah tingkat silikaannya, maka alat-alat tersebut hanya dicirikan adanya campur tangan manusia tanpa memperlihatkan sifat dasar bahan batuan.

Dilihat dari segi teknologi alat batu, teknologi yang digunakan adalah teknologi paleolitik Berdasarkan bekas pemakaian tampak bahwa alat tersebut penggunaannya tidak intensif. Hal tersebut tampak jelas pada kandungan temuan di Kotak D-5 dan D-2. Dilihat dari kandungan temuan pada kotak D-2 tampak adanya 2 lapisan budaya. Lapisan pertama merupakan lapisan atas dengan ciri alat-alat masif yang bervariatif (lihat foto 1), sedangkan lapisan kedua terletak pada lapisan yang lebih dalam dengan ciri alat-alat batu yang sangat terkonkresi dan tersedimentasi (lihat foto 2). Hal tersebut terlihat pada alat-alat yang terietak pada lapisan bawah berupa alat yang ditempeli lapisan tanah. krikil dan ada beberapa yang tersementasi dengan batu kristal, selain itu tampak jelas alat batu tersebut seperti dipernis (mengkilat). Berdasarkan kondisi temuan tersebut, dapat diketahui adanya 2 lapisan budaya industri litik.

Sejauh ini, kandungan temuan di Kotak D-2 tampak berbeda dengan kandungan temuan dan lapisan budaya pada kotak D-5. Pada kotak D-2 menunjukkan konsentrasi alat batu tanpa lapisan kerang. sedangkan kotak D-5 alat-alat batu ditemukan bercampur aduk dalam lapisan kerang (lihat gambar 5). 
Hasil perbandingan temuan yang ada pada setiap kotak menunjukkan bahwa kotak D-2 yang berada di sebelah kiri pintu masuk gua merupakan kotak paling padat temuan, sementara kotak B-10 yang terletak di ujung ruangan merupakan kotak yang paling miskin temuan. Kotak C-6 yang terletak di tengah ruang gua, dari segi kuantitas menunjukkan jumlah antara keduanya. Seandainya keletakan setiap kotak dan kedalaman penggalian yang telah dilakukan dapat dijadikan tolok ukur untuk menentukan kepadatan temuan dan mengacu pada pemanfaatan ruang, maka pemanfaatan puangan bagian depan di gua ini lebih penting, sementara ruang bagian dalam menempati prioritas selanjutnya. Dugaan seperti ini tampak lebih jelas setelah diadakan perbandingan temuan dengan keletakan kotak yang telah digali (lihat gambar 3 ).

Sehubungan dengan data arkeologi yang ada tampak jelas adanya pengulangan dalam hunian di Gua Macan. Hal itu dibuktikan dengan adanya 2 lapisan budaya yang tampak jelas pada frekuensi lapisan kerang yang ada. Pada lapisan kerang terdapat adanya konglomerat alas dan bongkahan-bongkahan batu gamping yang pemah berada pada posisi permukaan.

Berdasarkan stratigrafi yang tampak pada dinding barat kotak D-5 (lihat gambar 4) dapat dijelaskan sejarah geologi yang terjadi pada gua ini. Sejarah geologi ini berkaitan erat dengan proses hunian di Gua Macan. Kehidupan paling tua di Gua Macan ditunjukkan oleh lapisan budaya $\mathrm{C}$ dan setelah ditinggalkan penghuninya, lapisan ini terendam air dan terisi fragmen batu gamping dari reruntuhan dinding dan atap gua terutama stalagtit. Kondisi nil lapisan ini berupa cangkang kerang pada lapisan dasar. Setelah air menyusut, lapisan ini mengalami pemampatan atau pengerasan. Selanjutnya orosi air terjadi kembali dan terendapkan konglomerat alas. Kehidupan kedua terjadi kembali pada saat air sudah menyusut yaitu dengan bukti terbentuknya lapisan budaya B. Lapisan ini setelah ditinggalkan oleh penghuninya, terjadi proses rombakan yang cukup besar oleh air. Hal tersebut terbukti dengan adanya orientasi arah fosil-fosil cangkang dan adanya sisipan batu lempung, tanah hitam. dan batu gamping. Proses terakhir adalah lapisan B tererosi kembali dalam skala yang lebih kecil dibandingkan sebelumnya yang terjail bersamaan waktu dengan terjadinya pengendapan lapisan $\mathrm{A}$.

\section{Penutup}

Berdasarkan uraian di atas, tampak jelas bahwa penghunian di Gua Macan mengalami pengulangan hunian. Proses hunian terjadi disebabkan oleh pola adaptasi yang dipakai oleh penghuninya. Pada 
musim tertentu mereka menghuni gua, selanjutnya pada musim lain gua ditinggalkan, dan musim selanjutnya dihuni kembali. Proses hunian seperti itu lazim dilakukan oleh manusia masa itu mengingat pola hidupnya yang masih sangat bergantung pada potensi ekologi.

Secara tegas dapatlah disimpulkan, bahwa penghuni Gua Macan dalam pola huniannya dipengaruhi oleh faktor manusia dan faktor alam. Faktor manusia merupakan faktor yang dilakukan berdasarkan tuntutan hidup mereka dengan ketersediaan potensi ekologis sekitarnya. Sementara itu faktor alam, merupakan faktor yang sama sekali tidak melibatkan campur tangan manusia dan tak dapat dikendalikan manusia.

Faktor alam yang mempengaruhi hunian di Gua Macan tampak jelas dengan bukti terbentuknya lapisan budaya. Pada lapisan budaya telah diuraikan adanya orientasi arah cangkang dan konglomerat alas terutama pada lapisan B. Hal itu dapat dijadikan petunjuk bahwa di gua tersebut pernah terjadi perombakan arus yang masuk di dalam gua Melihat orientasi arah cangkang dapatlah diketahui awal dari arus penyebab rombakan. Awal arus tersebut adalah dari mulut gua bagian tinur (kanan), selanjutnya masuk ke dalam gua secara memutar dan keluar kembali melalui mulut gua bagian barat. Adanya arus rombakan tersebut didukung pula dengan adanya konglomerat alas yang berukuran kerikil sampai kerakal (2 - $64 \mathrm{~mm}$ "Skala Wentworth"). Konglomerat alas tersebut kontak langsung dengan lapisan C. Berdasarkan hal tersebut, secara tegas dapat diketahui bahwa pada masa tertentu pernah terjedi erosi satu arah yang cukup besar sehingga kondisi riil sekarang sudah terombakkan.

Kenyataan lain sehubungan dengan adanya hunian secara berulang dapat dibuktikan oleh temuan artefak batu. Sebagaimana telah diuraikan di atas, temuan alat-alat batu pada Gua Macan menunjukkan adanya dua tingkat budaya. Budaya pertama dicirikan oleh alat-alat batu masif yang bervariatif tanpa tersementasi, sedangkan lapisan kedua (tertua) dicirikan oleh alat-alat masif dengan kondisi yang tersementasi dan terkonkresi

Kedua kenyataan di atas yaitu data arkeologi dan geologi mem. buktikan adanya hunian secara berulang pada Gua Macan. Hunian secara berulang terjadi disebabkan pola musiman yang dianut oleh manusia masa itu dalam mempertahankan hidupnya. Dari musim ke musim mereka hidup dengan menggantungkan pada potensi alam yang tersedia dan diikuti oleh hunian pada tempat-tempat tertentu 
Binford, Lewis R., 1982, The Archeeology of Place, dalam Robert Whallon (ed.) Journal of Anthropological Archaeology I (1) : 5 . 31. New York: Academi Press

Heekeren, van H.R., 1972, Stone Age of Indonesia, VKI vol. 61, The Hague - Martinus Nijhoff.

Indah Asikin Nurani, 1995, LHPA Pola Pemanfaatan Lahan Gua Pada Komunitas Gua Gunung Watangan Tahap III, Yogyakarta Balai Arkeologi (tidak diterbitkan).

Mundarjito, 1993. Pertimbangan Ekologi dalam Penempatan Situs Masa Hindu-Budha di Daerah Yogyakarta. Kajian Arkeologi-Ruang Skala Makro, Disertasi, Jakarta: UI

1994. Arkeologi-Ekologi: Perspektif Ekologi dalam Penelitian Arkeologi, Evaluasi Hasil Penelitian Arkeologi, Palembang 11 s.d. 16 Oktober (belum diterbitkan).

Simanjuntak. Truman Harry, 1996, Akhir Plestosen dan Awal Holosen di Nusantara (Bahesan Tentang Karakter dan Kronologi Budaya), Pertemuan IImiah Arkeologi VII, Cipanas 12 s.d. 16 Maret 1996 (belum diterbitkan).

Soejono, R.P. (ed), 1984, Jaman Prasejarah di Indonesia, Sejarah Nasional Indonesia, Jilid I, Jakarta: Departemen Pendidikan dan Kebudayaan.

Sutikno, 1996, Pendekatan Geografi Untuk Kejian Arkeologi Spaliai. Evaluasi Hasil Penelitian Arkeologi Ujung Pandang 20 s d 26 September 1996 (belum diterbitkan). 


\section{Lampiran}

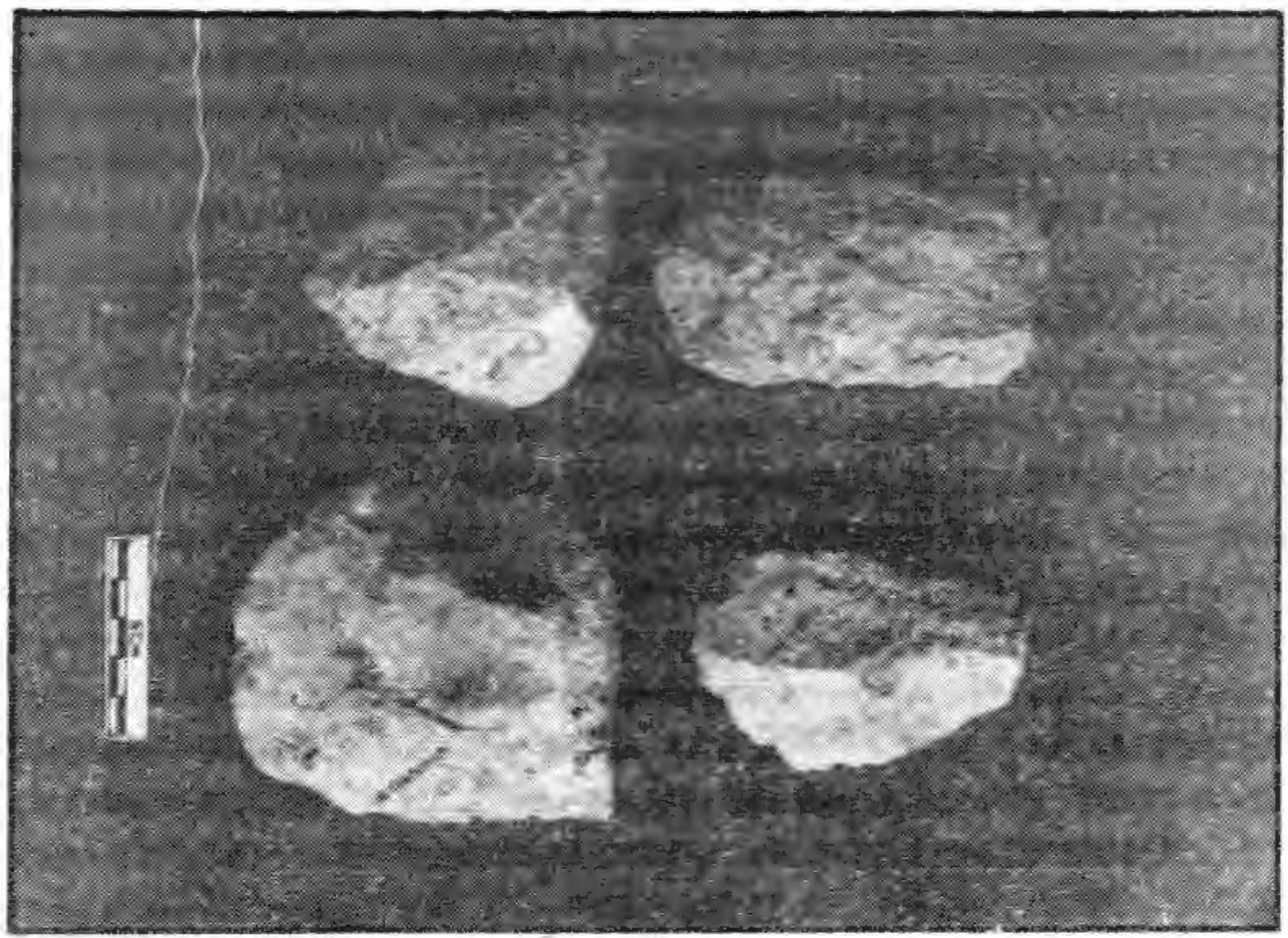

Foto 1. Alat-alat masif yang bervarıası pada lapısarı awal

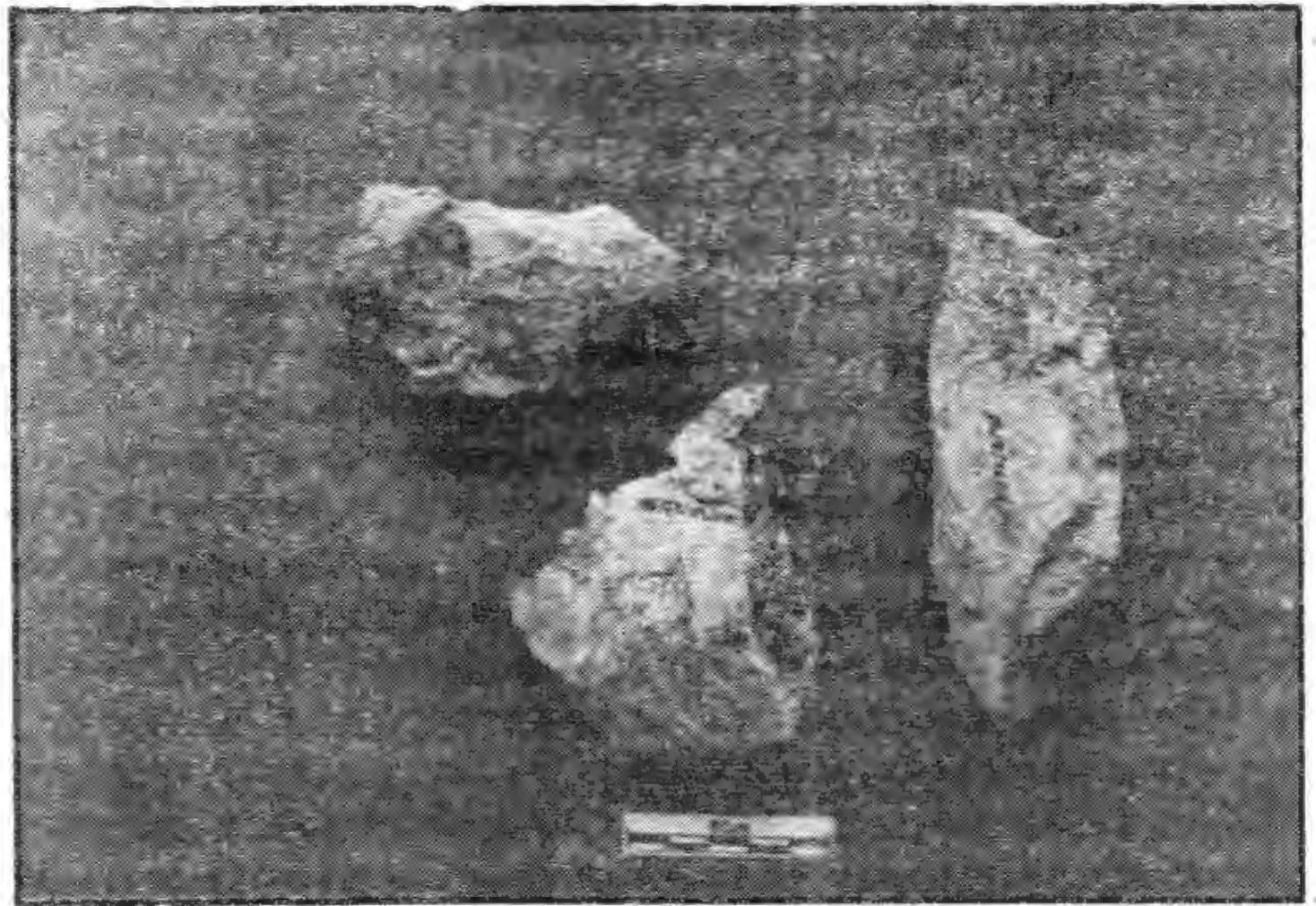

Foto 2. Alat-alat masif yang terkonkresi dan tersementası 


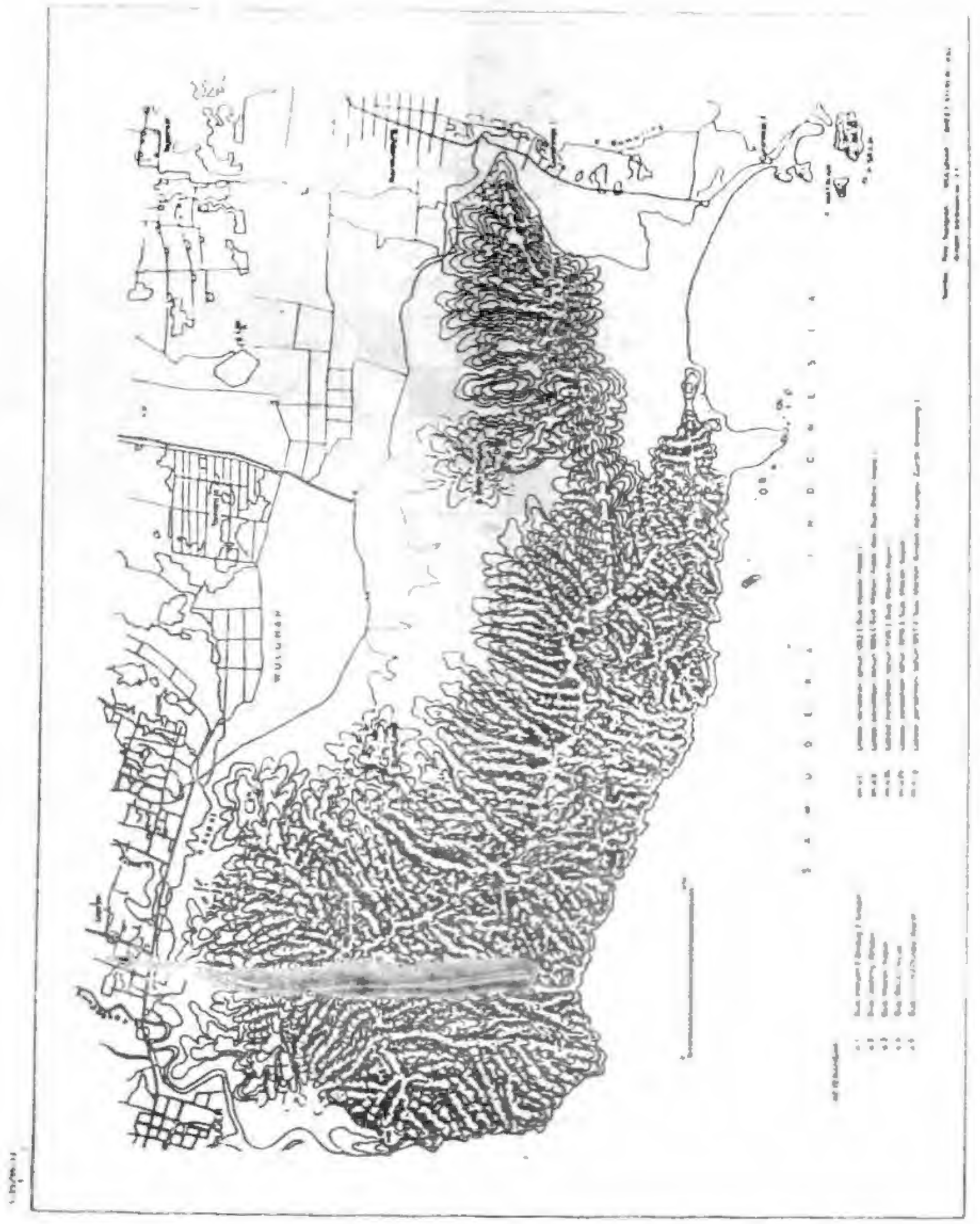




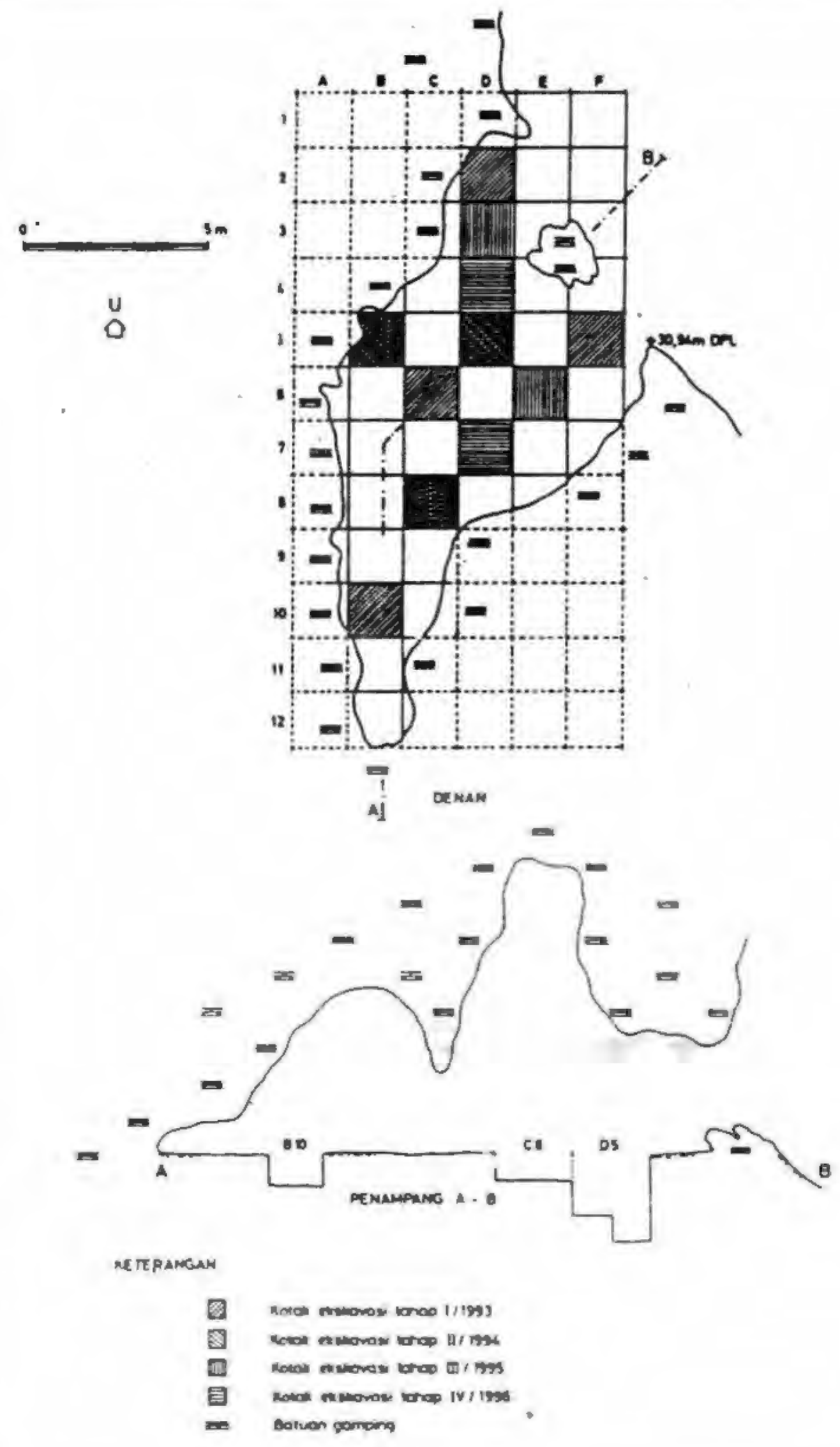

Gombar 2. Denoh Gu Macon, Kapet. Lopker. Wiluhan. Jember 
-4 1.

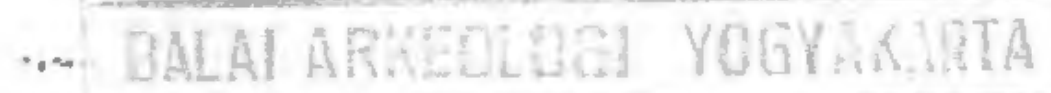

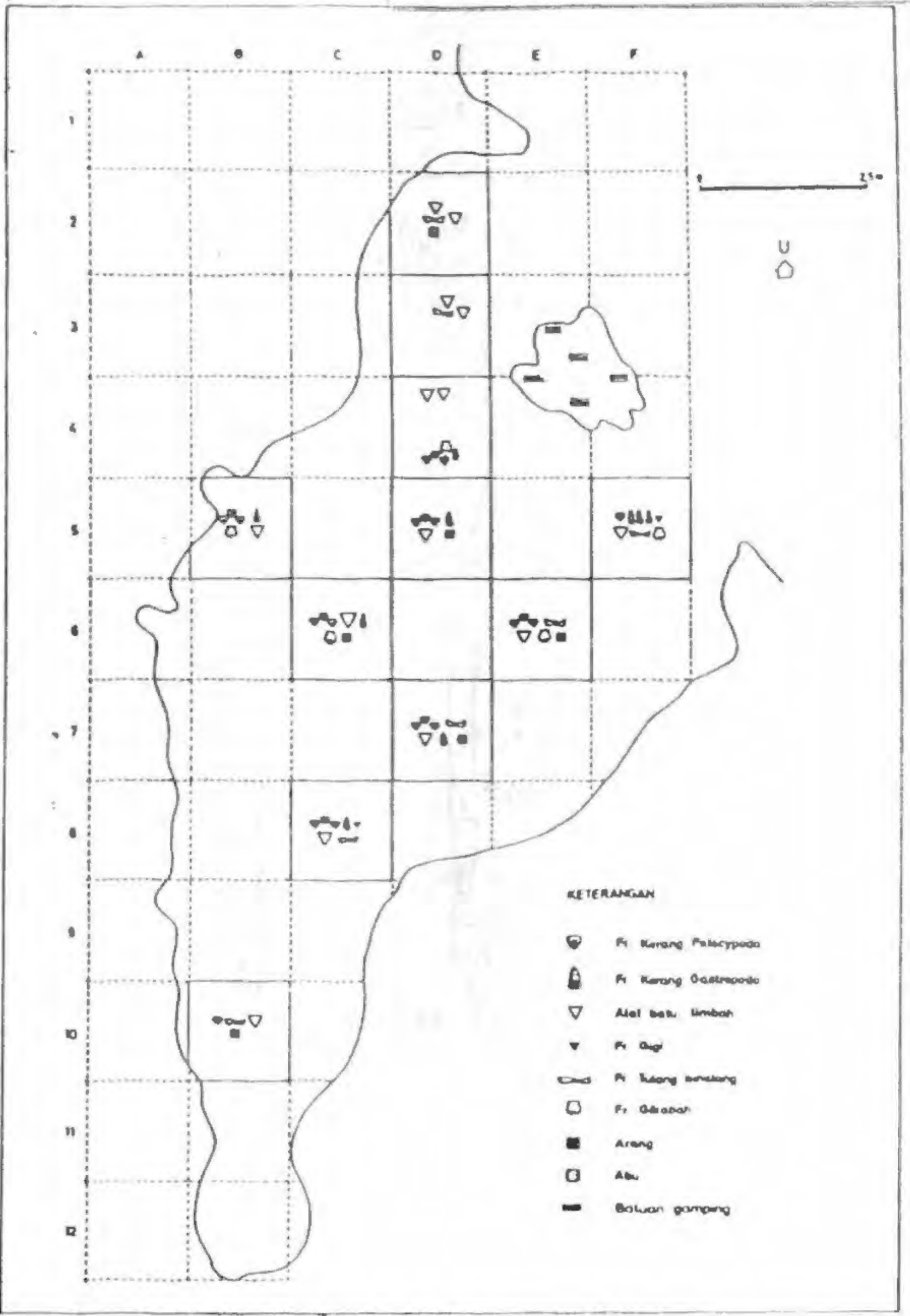

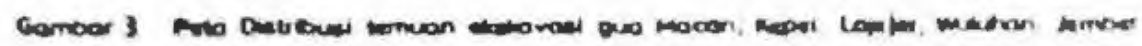




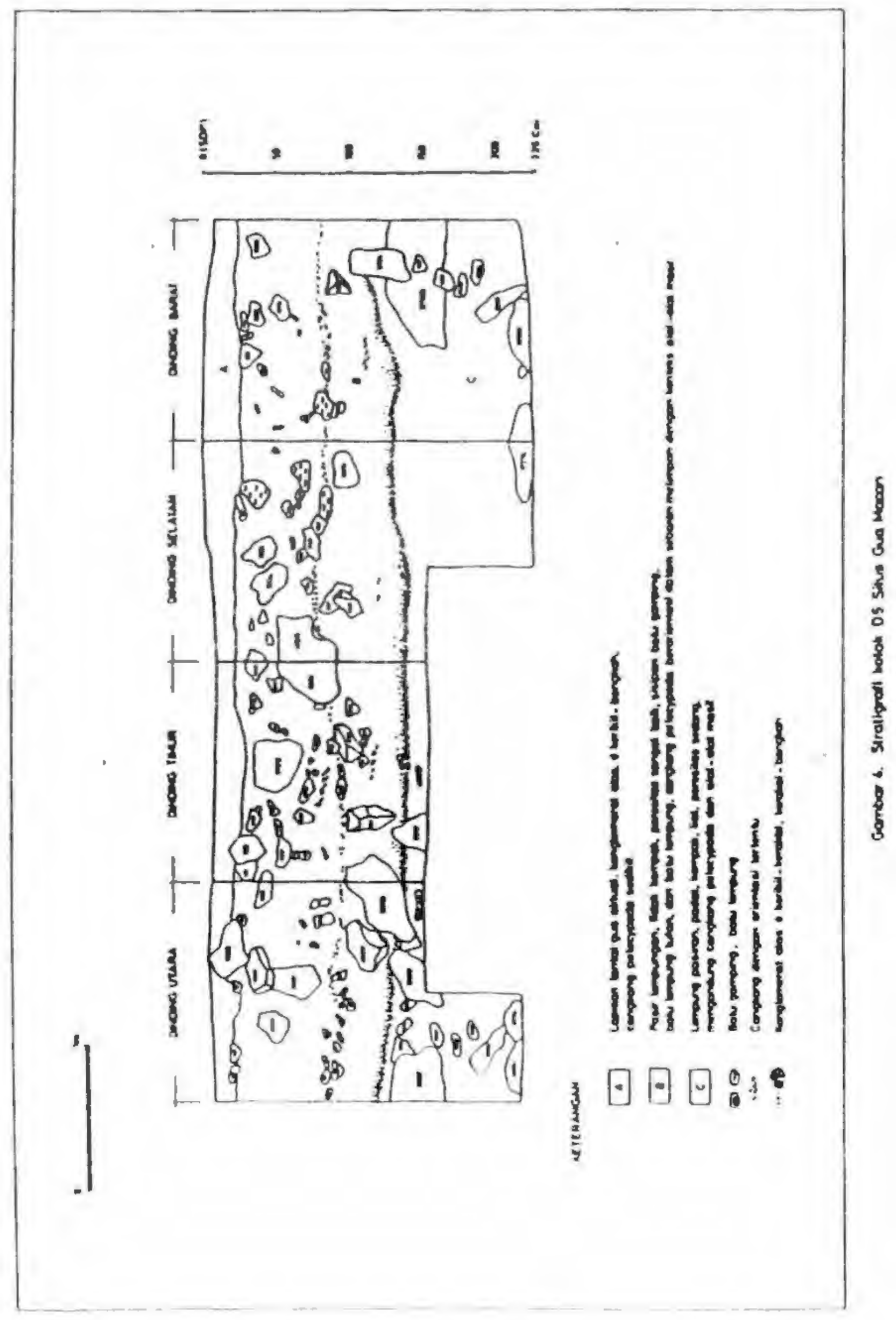




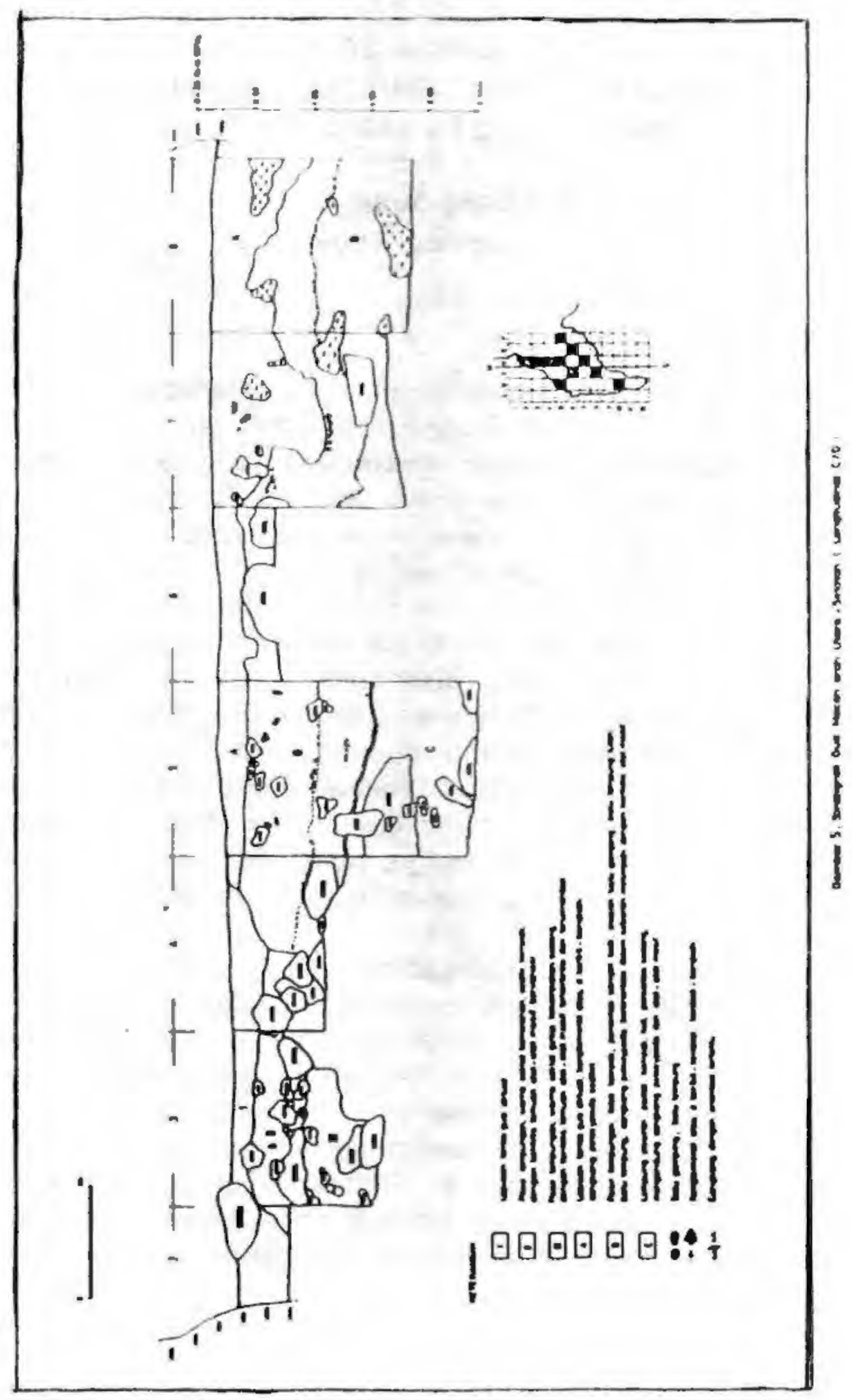

Berkala Arkeologi Th. XM - (2) - 